University of St.Gallen

\title{
New Evidence on the Announcement Effect of Convertible and Exchangeable Bonds
}

\author{
Manuel Ammann \\ Martin Fehr \\ Ralf Seiz
}

Working Paper Series in Finance

Paper No. 3 


\title{
NEW EVIDENCE ON THE ANNOUNCEMENT EFFECT OF CONVERTIBLE AND EXCHANGEABLE BONDS
}

\author{
Manuel Ammann, Martin Fehr and Ralf Seiz ${ }^{1}$ \\ Swiss Institute of Banking and Finance \\ University of St. Gallen \\ Rosenbergstrasse 52 \\ CH-9000 St. Gallen \\ Switzerland \\ January 2004
}

\begin{abstract}
This study investigates the announcement and issuance effects of offering convertible bonds and exchangeable bonds using data for the Swiss and German market during January 1996 and May 2003. The analysis shows that announcement effects of convertible bonds and exchangeable bonds are associated with significantly negative abnormal returns. Unlike previous studies, it also investigates the effect of the market return of the announcement effect and finds that the negative abnormal returns are significantly more pronounced when previous market returns have been negative. Furthermore, we analyze the relation between the announcement effects and equity components by controlling for the equity signal sent to the market. We find the size of the equity component of an issue to have a strong influence on the announcement effect for convertible but not for exchangeable securities and offer an explanation for this difference.
\end{abstract}

JEL code: G12, G14, G15, G32

Keywords: Convertible bonds, Exchangeable debt, Event study, Announcement effects

\footnotetext{
${ }^{1}$ Manuel Ammann is professor of finance, Martin Fehr and Ralf Seiz are research assistants at the University of St. Gallen. Tel: +4171-224-7090, Fax: +4171-224-7088, Email of corresponding authors: manuel.ammann@unisg.ch, ralf.seiz@unisg.ch.We would like to thank Bernd Brommundt, Michael Genser, Stephan M. Kessler, Michael Verhofen and Rico von Wyss for their helpful comments.
} 


\title{
NEW EVIDENCE ON THE ANNOUNCEMENT EFFECT OF CONVERTIBLE AND EXCHANGEABLE BONDS
}

\begin{abstract}
This study investigates the announcement and issuance effects of offering convertible bonds and exchangeable bonds using data for the Swiss and German market during January 1996 and May 2003. The analysis shows that announcement effects of convertible bonds and exchangeable bonds are associated with significantly negative abnormal returns. Unlike previous studies, it also investigates the effect of the market return of the announcement effect and finds that the negative abnormal returns are significantly more pronounced when previous market returns have been negative. Furthermore, we analyze the relation between the announcement effects and equity components by controlling for the equity signal sent to the market. We find the size of the equity component of an issue to have a strong influence on the announcement effect for convertible but not for exchangeable securities and offer an explanation for this difference.
\end{abstract}

\section{Introduction}

This study concentrates on the announcement effects of convertible and exchangeable bonds on the growing Swiss and German markets for these securities. Unlike previous studies, we analyze the influence of previous market returns on the announcement effect and show that the size of the announcement effects is greater when previous market returns 
have been negative. Furthermore, we show that the influence of the debt-equity composition is strong for convertible bonds but absent for exchangeable bonds, indicating that the issue of exchangeable bonds is no signal of the financing decision of the firm regarding debt vs. equity.

The announcement effect of different corporate securities has been the subject of numerous studies, such as Mikkelson and Partch (1986) for equity, Eckbo (1986) for bonds, Dann and Mikkelson (1984) for convertible securities and Gosh, Varma and Woolridge (1990) for exchangeable bonds, among others. Smith (1986) and Magennis et al. (1998) give an overview of the literature showing that the issuance of debt is not associated with a significant stock price reaction, the issuance of pure equity is associated with a significantly negative reaction of the stock price. Convertible bonds and exchangeable bonds have debt and equity components. As a consequence, the issuance of convertible bonds is associated with a significantly negative reaction of the stock price. However, the reaction is smaller than that of a pure equity issue. Several studies for the US market document a significantly negative (on average $-1.5 \%$ ) market response to convertible bond issues $^{2}$, confirming the hybrid nature of these financial instruments. Furthermore, these results support the models proposed by Myers and Majluf (1984), Brennan and Kraus (1987) and Kim (1990) ${ }^{3}$. However, Non-US studies show a mixed picture. Several Non-US studies show positive announcement effects of convertible bond issues. Examples are Roon and Veld (1998) for the Dutch market and Kang and Stulz (1996) for the Japanese market.

\footnotetext{
${ }^{2}$ See Roon and Veld (1998) for a summary of studies on announcement effects of convertible issues.

${ }^{3}$ The Myers and Majluf (1984) model is based on asymmetric information about the firm value. For convertible bonds, the Brennan and Kraus (1987) model and the Kim (1990) model are based on asymmetric information about the firm risk. These models predict a negative relationship between the announcement effect and the equity component at the issue.
} 
The issuance effect results analyzed in several studies present a mixed picture as well. For example, for the US domestic market, Dann and Mikkelson (1984), Mikkelson and Partch (1986) and Billingsley et al. (1990) find significantly negative stock market reactions on the issuance date whereas Kang and Stulz (1996) find a significantly positive market reaction in the Japanese market. In general, the stock market does not appear to react very strongly on the date of issue.

Gosh, Varma and Woolridge (1990) and Barber (1993) investigate the share price impact of the announcement of exchangeables by US firms. Gosh, Varma and Woolridge (1990) find a share price decline of the underlying firms of $-1.1 \%$ at the time of announcement. Barber (1993) states significantly negative abnormal return of $-1.0 \%$ for the underlying firm's share price around the announcement date. Gosh, Varma and Woolridge (1990) and Barber (1993) mention several rationales for their findings. Among other things, the authors argue that negative price reactions can be explained by (1) the offer's potential to reduce the ownership concentration in the common stock of the underlying, (2) the reduction of the probability of a change in control (and its associated take-over premium), (3) the signal of the issuer of a decreased likelihood of a bidder-target relationship, and (4) that the negative share price reactions results from the negative signal the issuer sends to the market at announcement. Barber (1993) argues that the negative price reactions of the underlying share are due to information regarding the future prospects of the firm brought to the market. 
In this study, announcement and issuance effects of convertible bonds and exchangeable bonds are studied for the Swiss and German market, where no such study exists at this time. Announcement effects are investigated for 55 convertibles and 28 exchangeables issued from January 1996 to May 2003. Similar to previous studies of the US market, we find a significantly negative average cumulative abnormal return in the period ${ }^{4}[0,1]$ of $1.61 \%$ for the complete sample encompassing convertibles and exchangeables in Switzerland and Germany. Furthermore, there are significantly positive average cumulative abnormal returns in a period before the announcement day $[-5,-2]$ of $+0.78 \%$.

For the sub-samples of Switzerland and Germany, we find significantly negative average cumulative abnormal returns in the period $[0,1]$ of $-1.03 \%$ and $-2.43 \%$, respectively. Although both countries show significantly negative market reactions, the German market reacts significantly stronger than the Swiss market. For the sub-sample defined by the two types of securities, i.e., convertibles and exchangeables, there are negative average cumulative abnormal returns in the period $[0,1]$ of $-1.36 \%$ and $-2.09 \%$, respectively.

To determine the market reactions on the issuance date a new sub-sample is generated. The issuance effects show non-significant and slightly positive average cumulative abnormal return for the period $[0,1]$, where $t=0$ denotes the issuance date.

\footnotetext{
${ }^{4}$ We denote $t=0$ as the announcement day. Because the announcement information used in this study is provided by Reuters, a continuous-time information provider, the event window is defined as the period between the announcement date $(t=0)$ and the day after the announcement $(t=1)$, i.e., $[0,1]$. We assume that once the firm has announced an issue $(t=0)$ the information provider reports this information on the same day. In case the market is already closed, market reactions are possible a day after the announcement $(t=1)$. In this respect our analysis differs from studies using newspapers as information providers, where the event window is often chosen as $[-1,0]$ because of the delayed information in the newspapers.
} 
Moreover, we provide a more detailed analysis of market reactions upon announcement of convertibles and exchangeables on the Swiss and German market by controlling for the equity signal sent to the market and the previous market returns. As proposed by Burlacu (2000) and Lewis et al. (2003), we use the DELTA ${ }^{5}$ as a proxy for the equity component of the convertibles and exchangeables. Higher measures of DELTA coincide with more negative cumulative abnormal returns. These results are highly significant for the complete sample (convertibles and exchangeables) and for the sub-sample of convertibles only. However, the DELTA is not significant for the exchangeables. These results indicate that for convertibles, managers (insiders) signal information about the firm value or firm risk and therefore there is a negative relationship between the announcement effect and the equity component of the issue. However, for exchangeables, managers do not control the equity component and therefore the DELTA is not significant for exchangeables. But there is an asymmetric information problem regarding the underlying firm quality for exchangeables as well, as our empirical results indicate. Danielova (2003) shows that exchangeable bond issuers take advantage of transitory windows of opportunity when they perceive underlying stock to be overvalued and that the driving force behind a markettiming behavior of issuers is their perception of temporary mispricing of the associated underlying stock. The negative price reactions of the underlying share for exchangeables are due to uncertain information regarding the future prospects of the firm brought to the market by the issuer. This signal is similar to an announcement of a large sale by a shareholder.

\footnotetext{
${ }^{5}$ Sensitivity of the bond with respect to the underlying (s. Section 2).
} 
The underlying stock price of convertibles and exchangeables can be affected not only by a information signal regarding the future prospects of the firm, but also by liquidity costs or price-pressure $^{6}$. We argue that these effects, including the sell-signal, are stronger in a down market than in an up market. Therefore abnormal returns should be more pronounced (more negative) in down-markets. Our empirical evidence strongly supports this hypothesis. We show that the abnormal returns for the period $[0,1]$ are significantly influenced by the market return before the announcement (measured, for example, during the period $[-200,-20])$.

The remainder of this paper is structured as follows. In Section 2, the data description is presented. The event study methodology is described in Section 3. The announcement effect of Swiss and German convertibles and exchangeables are discussed in Section 4. In Section 5 the issuance effects are studied. In Section 6, the cross-sectional differences between the announcement effects are analyzed using regression analysis. Section 7 concludes.

\section{Data description}

The complete sample consists of convertible bonds and exchangeable bonds issued from January 1996 to May 2003 by Swiss and German companies. During this period a total of 203 convertibles and exchangeables are identified. Exchangeables issued by Non-Swiss or Non-German companies are included in our sample if the bond can be converted into the stock of a Swiss or German firm. We eliminate 120 securities from this basis sample

\footnotetext{
${ }^{6}$ See Harris and Gurel (1986), Hess and Frost (1982), Holthausen and Leftwich (1987), Kraus and Stoll
} 
according to the following seven selection criteria: announcement date cannot be defined accurately (25), conversion stock is not yet listed on the stock exchange (1), securities have a nominal issuing volume smaller than $\$ 10$ Mio. (63), data for securities is unavailable (9), announcements of these issues are accompanied by the announcement of important information such as expected or realized earnings, expected dividends, ratings, unexpected depreciation, restatements, mergers and acquisitions or issuance of other securities two days before or after the announcement (22). Finally, our sample consists of 55 announcements of convertibles and 28 announcements of exchangeables.

The announcement date is defined as the first date on which the announcement appears in the information provider Reuters. The announcements have to be precise in terms of issuing volume. The issuing date is defined as the date on which the companies publish the definitive conditions. In principle, Reuters publishes news continuously. However, it is possible that the news is published when the market is closed and therefore information is not processed until the next day. For this reason, the time period $[0,1]$ is analyzed in this study.

The sensitivity of the securities to their underlying common stocks (DELTA) is used as a measure for the equity component ${ }^{7}$. Under the restrictive assumption that the securities may be considered as the sum between a standard bond and an European warrant entitling the owner to purchase a fraction of the equity upon an exercise payment equal to the principal on the bond, the DELTA of the securities equals the DELTA of the embedded warrant. Under the Black-Scholes assumptions, the value of DELTA is:

(1972) and Scholes (1972) among others. 


$$
D E L T A=e^{-\delta T} N\left\{\frac{\left[\ln (S / C P)+\left(r-\delta+\sigma^{2} / 2\right) T\right]}{\sigma T^{1 / 2}}\right\}
$$

where $S$ is the current price of the underlying stock, $C P$ the conversion price, $r$ the continuously compounded risk-free rate, $\sigma$ the volatility, $T$ the number of years to maturity, $\delta$ the continuously compounded dividend yield, and $N($.$) is the cumulative$ probability under a standard normal distribution function.

The 55 convertibles and 28 exchangeables have been issued by 60 companies with a total issuing volume of USD 38.5 Bn and an average issuing amount of USD 463.6 Mio. 36 of the 55 convertibles in the sample are issued by Swiss firms, 19 by German firms. Correspondingly, 13 of the exchangeables can be exchanged into stock of Swiss firms, 15 into stock of German firms. In the complete sample 19 companies belong to the financial service sector and 64 to the industrial sector. Summary statistics for the issues and issuers for the complete sample are presented in Table 1.

\section{[Table 1]}

We grouped the complete sample into two different sub-samples for a detailed analysis. The first sub-sample distinguishes between the two analyzed countries (Germany and Switzerland) whereas the second sub-sample distinguishes between the type (convertibles and exchangeables) of the securities. For the exchangeables the issuer is different from the

\footnotetext{
${ }^{7}$ See Burlacu (2000) and Lewis et al. (2003).
} 
underlying stock, therefore we use two different parameters: PERCISSUER that is the issuing amount per market value of issuer and PERCUNDERL that is the issuing amount per market value of the underlying company. For convertibles these values are equal per definition. Table 2 and Table 3 show the characteristics for these two sub-samples.

[Table 2]

[Table 3]

\section{The event study methodology}

Announcement and issuance effects are generally measured using a standard event study methodology as described in Brown and Warner (1985). Abnormal returns are defined using an Ordinary Least Squares (OLS) market model ${ }^{8}$ regression

$$
A R_{i t}=R_{i t}-\hat{\alpha}_{i}-\hat{\beta}_{i} R_{m t}
$$

where $A R_{i t}$ is the abnormal return for firm $i$ on day $t, R_{i t}$ denotes the return on security $i$ on day $t$ and $R_{m t}$ is the return of the market index on day $t$. The parameters $\hat{\alpha}_{i}$ and $\hat{\beta}_{i}$ can be estimated over the estimation period $[-200,-21]$ before the announcement date $(t=0)$ by running an OLS regression of the stock returns on a constant and the return on the market index. The chosen market indices are the Swiss Performance Index (SPI) and the Composite DAX (CDAX) for the Swiss and German sub-sample respectively. Denoting 
the announcement date as day 0 , the event window ranges from day 0 to day $1([0,1])$. Abnormal returns are calculated for the period $[-20,20]$.

Following MacKinlay (1997), the abnormal return observations have to be aggregated in order to draw overall inferences for the announcement. The aggregation is along two dimensions - through time and across securities. Define $C A R_{i}\left(t_{1}, t_{2}\right)$ as the cumulative abnormal return (CAR) from $t_{1}$ to $t_{2}$ where $t_{1}$ is the beginning and $t_{2}$ is the end of the event window. The CAR is the sum of the included abnormal returns,

$$
\operatorname{CAR}_{i}\left(t_{1}, t_{2}\right)=\sum_{t=t_{1}}^{t_{2}} A R_{i t}
$$

The average abnormal return (AAR) is defined as the sum over all securities of the abnormal returns (AR) divided by the number of securities $(N)$,

$$
A A R\left(t_{1}, t_{2}\right)=\frac{1}{N} \sum_{i=1}^{N} A R_{i}\left(t_{1}, t_{2}\right)
$$

Furthermore, define the average cumulative abnormal return (CAAR) as

$$
\operatorname{CAAR}\left(t_{1}, t_{2}\right)=\frac{1}{N} \sum_{i=1}^{N} C A R_{i}\left(t_{1}, t_{2}\right)
$$

\footnotetext{
${ }^{8}$ Compare Fama et al. (1969) for further discussion.
} 
where the CAAR is the sum over all securities $(N)$ of the CAR divided by the number of securities.

Tests of statistical significance are based both on standardized abnormal returns ${ }^{9}$ (Standardized t-Test) and a non-parametric test (Rank Test) of Corrado (1989). Assuming that the abnormal returns are multivariate normal and cross-sectionally independent, the null hypothesis that the mean abnormal return is zero is tested with the following statistic $\left(J_{1}\right)$ :

$$
J_{1}\left(t_{1}, t_{2}\right)=\frac{1}{\sqrt{N}} \sum_{i=1}^{N} \sum_{t=t_{1}}^{t_{2}} \frac{A R_{i t}}{S_{i T_{1}}}
$$

whereas the $S_{i T_{1}}$, denotes the standard deviation of the sum of the $A R_{i t}$ series over the time period $T_{1}$ from $t_{1}$ to $t_{2}$ and is given by

$$
S^{\prime}{ }_{i T_{1}}=\left\{\hat{\sigma}_{i}^{2}\left[T_{1}+\frac{T_{1}^{2}}{A}+\frac{T_{1}^{2}\left(\bar{R}_{m T_{1}}-\bar{R}_{m}\right)^{2}}{\sum_{t=1}^{A}\left(R_{m t}-\bar{R}_{m}\right)^{2}}\right]\right\}^{\frac{1}{2}} .
$$

The value $\hat{\sigma}_{i}^{2}$ is the mean square error of the market model regression for firm $i, A$ is the number of returns in the estimation period, $\bar{R}_{m}$ is the mean market index return over the estimation period, and $\bar{R}_{m T_{1}}$ is the mean market index return during the event window $T_{l}$.

\footnotetext{
${ }^{9}$ See Fields and Mais (1991) and Mikkelson and Partch (1988).
} 
The statistic in Equation (2.6) has an asymptotically standard normal distribution and $\mathrm{N}$ denotes the sample size.

The rank test proposed by Corrado (1989) does not require symmetry in cross-sectional abnormal returns distributions for correct specification. This rank test offers improved specifications under the null hypothesis and more power under the alternative hypothesis of abnormal security-price performance. The null hypothesis that the mean abnormal return is zero is tested with the following asymptotically standard normal distribution statistic $\left(J_{2}\right)$ :

$$
J_{2}(t)=\frac{1}{N} \sum_{i=1}^{N}\left(K_{i t}-\bar{K}\right) / S^{\prime}(K)
$$

where

$$
S^{\prime}(K)=\sqrt{\frac{1}{k} \sum_{t=1}^{k}\left(\frac{1}{N} \sum_{i=1}^{N}\left(K_{i t}-\bar{K}\right)\right)^{2}}
$$

and

$$
\bar{K}=\frac{1}{2} k=\frac{1}{2}\left(T_{0}+T_{1}\right)
$$

Where $K_{i t}$ is the rank of $k$ abnormal returns observed in the estimation period $\left(T_{0}\right)$ and in the event window $\left(T_{1}\right)$ and $\bar{K}$ is the expected mean rank. 


\section{Announcement effects}

Table 4 shows the average abnormal returns (AAR) for the period $[-5,5]$ and the average cumulative abnormal returns (CAAR) for selected time periods for the complete sample. We observe that there is a significant negative average abnormal return of $-1.41 \%$ at the announcement day and there are significant positive average abnormal returns of $+0.65 \%$ and $+0.30 \%$ for one and two days before the announcement. The significantly positive abnormal returns in the pre-announcement period suggest that managers tend to announce these securities when stock prices have increased. Furthermore Table 4 shows that there is a significant negative average cumulative abnormal return of $-1.61 \%$ for the period $[0,1]$.

\section{[Table 4]}

Table 5 shows the AAR and CAAR for the sub-samples Switzerland and Germany. For the sub-sample Switzerland there is a negative but not significant average abnormal return of $-0.84 \%$ at the announcement day. However, there is a significant average cumulative abnormal return for the period $[0,1]$ of $-1.03 \%$ at the $10 \%$-level. For the sub-sample Germany, at the announcement day there is a highly significant negative average abnormal return of $-2.24 \%$ at the $1 \%$-level, and for the period $[0,1]$ there is a highly significant average cumulative abnormal return of $-2.43 \%$ at the $1 \%$-level. Note that we observe significant positive average abnormal returns for the sub-sample Switzerland a day before the announcement. For the sub-sample Germany these returns are positive as well, however, these average abnormal returns are not significant. The null hypothesis for 
identical means can be rejected at the 5\%-level as well for the announcement day as for the period $[0,1]$.

\section{[Table 5]}

The results presented in Table 6 for the sub-samples convertibles and exchangeables show that for both sub-samples there is a significant negative average abnormal return at the announcement day. However, the average abnormal return for the convertibles of $-1.12 \%$ is smaller than the average abnormal return for the exchangeables with $-1.99 \%$. In the period $[0,1]$ average cumulative abnormal returns are significantly negative for convertibles as well as exchangeables. The CAAR for the convertibles is $-1.36 \%$ and the CAAR for the exchangeables is $-2.09 \%$, again significantly lower for the exchangeables than for the convertibles. The null hypothesis for identical means can be rejected at the $5 \%$-level for the period $[0,1]$. One day before the announcement the average abnormal returns are significantly positive for the convertibles similar to the period $[-5,-2]$ where we found a significantly positive average cumulative abnormal return at the $10 \%$-level.

\section{[Table 6]}

If the sample is further divided in German convertibles, German exchangeables, Swiss convertibles, and Swiss exchangeables, the following mean announcement effects result: $-1.56 \%$ for German convertibles (19 bonds), $-3.11 \%$ for German exchangeables (15 bonds), $-0.89 \%$ for Swiss convertibles (36 bonds), and $-0.69 \%$ for Swiss exchangeables (13 bonds). These sub-samples show that the larger effect observed for exchangeables 
compared to convertibles, as illustrated in Table 6, is mainly caused by German exchangeables. On the Swiss market, such a difference between exchangeables and convertibles cannot be observed. The larger announcement effect of German issues compared to Swiss issues, as shown in Table 5, however, applies to both convertibles and exchangeables.

The three main results of this section are the following: First, similar to some US-studies, we find significantly negative average (cumulative) abnormal returns of about $-1.5 \%$ at the announcement day and the period $[0,1]$ for the complete sample. Second, we show that the German market reacts significantly stronger than the Swiss market, and, third, the market reaction for exchangeables is more pronounced than for convertibles in Germany, but not in Switzerland.

\section{Issuance effects}

The time period between the announcement and the issue is often very short and therefore the effects of a security issue could be overlaid by the effects caused by the announcement. Therefore we defined a new complete sample where the period between the announcement and the issue has to be at least two days. 36 securities (29 convertibles and 7 exchangeables) with an average time period of 15.7 days between the announcement day and the issue of the security fulfill this criterion. Table 7 shows the results for the issuance effects of the new sub-sample. Note that we defined $t=0$ for the day of the issue if we determine the issuance effects. For comparison there are the announcement effects for the new sub-sample with $t=0$ for the day of announcement as well. We observe that there are 
no significant effects concerning average (cumulative) abnormal returns when the securities are issued, however, the abnormal returns are slightly positive. Moreover Table 7 confirms the previous results: significantly negative average abnormal returns at the announcement day, significantly negative average cumulative abnormal returns during the period $[0,1]$ and significant positive average cumulative abnormal returns in the time period $[-5,-2]$ before the announcement.

\section{[Table 7]}

\section{Cross-sectional regression analysis}

We also calculate the results for a regression analysis. First we want to test if the DELTA of the tested securities is a reasonable proxy for the equity-character, second we want to test if the market returns before the announcement (in the period ${ }^{10}[-200,-20]$ ) have explanatory character for the abnormal returns, third we want to analyze the difference in abnormal returns for the four sub-samples (Convertibles, Exchangeables, Germany and Switzerland) and fourth we want to analyze if the abnormal returns differ from small or large issues or issuers. Therefore the following regression equation is estimated:

$$
\begin{aligned}
\text { CAR }_{i}(0,1)= & \beta_{0}+\beta_{1} \text { DELTA }_{i}+\beta_{2} \text { MARKETRETURN }_{i}+\beta_{3} \text { DCOUNTRY }_{i} \\
& +\beta_{4} \text { DTYPE }_{i}+\beta_{5} \text { LNAMTISSD }_{i} \\
& +\beta_{6} \text { LNMVUNDERL }_{i}+\beta_{7} \text { PERCUNDERL }_{i}+\varepsilon_{i}
\end{aligned}
$$


where $\operatorname{CAR}_{i}(0,1)$ is the cumulative abnormal return for the period $[0,1]$ of security $i$, $\operatorname{DELTA}_{i}$ is the sensitivity of the security with respect to the underlying, MARKETRETURN is the market return in the period $[-200,-20]$ before the announcement, DCOUNTRY $Y_{i}$ is a dummy variable for the two countries analyzed which is 0 for a German issue and 1 for a Swiss issue, $D T Y P E_{i}$ is a dummy variable for the type of the security which is 0 for an exchangeable issue and 1 for a convertible issue, $\operatorname{LNAMTISSD}_{i}$ is the logarithm of the amount issued, $L N M V U N D E R L_{i}$ is the logarithm of the market value of the underlying company and PERCUNDERL $L_{i}$ is the issuing amount per market value of the underlying company.

Table 8 shows that higher measures of DELTA coincide with more negative cumulative abnormal returns, these results are significant at the 1\%-level for all regressions conducted. High DELTAs imply similarity to equity (high announcement effect), low DELTAs similarity to debt (low announcement effect). These findings are similar to results concerning the American market and lend support to the models proposed by Myers and Majluf (1984), Kim (1990) and Davidson et al. (1995).

\section{[Table 8]}

Furthermore, the parameter MARKETRETURN is highly significant and positive at the $1 \%$ level for all regressions conducted. These results show that the cumulative abnormal returns are significantly higher (less negative) in times of good markets. Several

\footnotetext{
${ }^{10}$ Regressions using different periods (e.g. [-110,-20], [-290,-20], [-380,-20]) for the market returns before the announcement day were also conducted. The results were not materially different from those based on the period $[-200,-20]$.
} 
explanations for this effect are conceivable. For example, it is possible that asymmetric information signal regarding the risk and valuation of the firm has a stronger effect in weak markets, when risk premia are higher. Additionally, the price pressure caused by the sale of a convertible issue may have a stronger effect on prices when markets are weak and, therefore, the liquidity of the market may be reduced. Issuing convertible or exchangeable bonds during weak markets may also be seen as a signal for financial distress.

The dummy for the two different countries DCOUNTRY is not significant. However, the positive coefficients indicate that the announcement effects are more positive for Swiss securities than for German securities ${ }^{11}$. This result supports the findings in Section 4 that the cumulative abnormal returns are more negative for German securities than for Swiss securities. In regression (5) we analyzed the impact of the security (the dummy DTYPE is 1 for convertibles and 0 for exchangeables). The coefficient turned out to be also positive, but not significant ${ }^{12}$. This result supports the findings in Section 4 that the cumulative abnormal returns are more negative for exchangeables than for convertibles. Regressions (6) to (8) analyze the impact whether large issues or large firms behave differently than small issues or small firms. Table 8 shows no significant results for these parameters. Regression (9) to (11), where we combined all parameters, give similar results as we have discussed above.

[Table 9]

\footnotetext{
11 The dummy is 1 for a Swiss security and 0 for a German security.

${ }^{12}$ Regression (10) shows that the coefficient for the dummy DTYPE is significant at the $10 \%$-level.
} 
Table 9 shows the cross-sectional analysis separately for convertible and exchangeable bonds. For all cross-sectional regressions, the parameter MARKETRETURN is positive and of very similar size. While it is significant in most regressions, the level of significance tends to be higher for convertibles. This effect can be explained with the larger size of the convertibles sub-sample (55 bonds) compared the exchangeables sub-sample (28 bonds). It is interesting that convertibles and exchangeables are equally affected by the variable MARKETRETURN. Apparently, the valuation signals and the liquidity effects associated with issues are similar for exchangeable and convertible bonds.

For convertibles, the parameter DELTA is still negative and highly significant, as can be seen in Table 9. In fact, the coefficient is substantially smaller (approximately -0.14 ) than in Table 8 (approximately -0.09). The reason is the difference between convertibles and exchangeables. For exchangeables, the DELTA coefficient is positive, though not significantly different from zero. This difference between convertibles and exchangeables can be explained by the financing decision of the firm. DELTA determines the equity and debt composition of the issue. This composition is relevant in the case of convertibles because it signals the financing decision of the firm, i.e. a high DELTA implies a high extent of equity financing. In the case of exchangeables, however, a high DELTA does not imply equity financing of the issuing firm and, consequently, is not associated with the strong announcement effect seen for equity issues. 


\section{Conclusion}

We present an empirical analysis of announcement and issuance effects of convertible and exchangeable bonds for the Swiss and German market. Similar to previous work on the US market, we find significantly negative average (cumulative) abnormal returns of about $-1.5 \%$ on the announcement day for the complete sample and observe no significant effects on the day of issue. Moreover, we observe that the German market reacts significantly stronger than the Swiss market.

Furthermore, we analyze the market reaction upon the announcement of convertible and exchangeable bonds by controlling for the equity signal sent to the market and, unlike previous studies, by controlling for the previous market returns. In particular, we show that the negative abnormal returns are more pronounced when previous market returns have been negative. Thus, falling markets tend to increase the effect of signals sent to market participants, perhaps partly due to liquidity effects. Additionally, the issue of convertibles or exchangeables during weak markets may be interpreted by market participants as a signal of financial distress.

As a further contribution, we investigate the relationship between the announcement effect and the debt and equity composition of the issued bonds. The evidence supports our hypothesis that the proportion between equity and debt components should influence the announcement effects of convertible bonds but not of exchangeable bonds because, in the latter case, no financing decision regarding debt vs. equity is signaled by the issuer. 


\section{References}

BARBER, B. (1993): “Exchangeable Debt,” Financial Management, 22 (2), 48-60.

BILLINGSLEY, R. S., LAMY, R. E. AND D. M. SMITH (1990): "Units of debt with warrants: evidence of the "penalty-free" issuance of an equity-like security," The Journal of Financial Research, 8 (3), 187 - 199.

BRENNAN, M. AND A. KRAUS (1987): "Efficient financing under asymmetric information.," Journal of Finance, 42 (5), 1225-1243.

BROWN, S.J. AND J.B. WARNER (1985): "Using daily stock returns: The case of event studies," Journal of Financial Economics, 3-31.

BURLACU, R. (2000): "New evidence on the pecking order hypothesis: the case of French convertible bonds," Journal of Multinational Financial Management, 10, 439-459.

CORRADO, C. J. (1989): “A nonparametric test for abnormal security returns," Journal of Financial Economics, 23, 385 - 395.

DANIELOVA, A.N. (2003): "When do firms issue exchangeable debt?," Working Paper, Kelly School of Business, Indiana University

DANN, L.Y. AND W. H. MIKKELSON (1984): „Convertible debt issuance, capital structure change and financing-related information: Some new evidence," Journal of Financial Economics, 13, 157-186.

DAVIDSON, W.N., GLASCOCK, L.J. AND T.V. SCHWARZ (1995): "Signalling with convertible debt," Journal of Financial Quantitative Analysis, 3, 425-441.

DE ROON, F. AND C. VELD (1998): "Announcement Effects of Convertible Bond Loans and Warrant-Bond Loans: An empirical analysis of the Dutch Market," Journal of Banking \& Finance, 22, 1481-1506.

ECKBO, B.E. (1986): "Valuation effects of corporate debt offerings," Journal of Financial Economics, 15, 119-151.

FAMA, E. F., FISHER, L., JENSEN, M. AND R. ROLL (1969). “The adjustment of stock prices to new information," International Economic Review, 10, 1 - 21.

FIELDS, L. P. AND E. L. MAIS (1991): "The valuation effect of private placements of convertible debt," Journal of Finance, 46 (5), 1925 - 1932.

GOSH, C., VARMA, R. AND R: WOOLRIDGE (1990): “ An Analysis of Exchangeable Debt Offers," Journal of Financial Economics, 28 (1-2), 251-263 
HARRIS, L. AND E. GUREL (1986): "Price and Volume Effects Associated with Changes in the S\&P 500 List: New Evidence for the Existence of Price Pressures," Journal of Finance, 16 (4), 815-829.

HESS, A. C. AND P.A. FROST (1982): "Tests for Price Effects of New Issues of Seasoned Securities," Journal of Finance, 36, 11-25.

HOLTHAUSEN, R. W. AND R. W. LEFTWICH (1987): “ The Effect of large Block Transactions on Security Prices," Journal of Financial Economics, 19, 237-267.

KANG, J. K. AND R. M. STULZ (1996), "How different is Japanese corporate finance? An investigation of the information content of new security issues," Review of Financial Studies, 9 (1), 109 - 139.

KIM, Y. O. (1990): "Informative Conversion Ratios: A Signalling Approach," Journal of Financial and Quantitative Analysis, 25 (2), 229 - 243.

KRAUS, A. AND H. R. STOLL (1972): "Price Impacts of Block Trading on the New York Stock Exchange," Journal of Finance, 27, 569-588.

LEWIS, C. M., ROGALSKI, R. J. AND J.K.SEWARD (2003): "Industry conditions, growth opportunities and market reactions to convertible debt financing decisions," Journal of Banking \& Finance, 27, $153-181$.

MACKINLAY, A. C. (1997): "Event studies in economics and finance," Journal of Economic Literature, 35, 13 - 39.

MAGENNIS, D., WATTS, E. AND S. WRIGHT (1998): "Convertible notes: the debt versus equity classification problem," Journal of Multinational Financial Management, 8, 303-315.

MIKKELSON, W. H. AND M. M. PARTCH (1986): „Valuation effects of security offerings and the issuance process," The Journal of Financial Economics, 15, 31 - 60.

MIKKELSON, W. H. AND M. M. PARTCH (1988): „Withdrawn security offerings,” The Journal of Financial and Quantitative Analysis, 23 (2), 119 - 133.

MYERS, S. C. AND N. S. MAJLUF (1984): “ Corporate financing and investment decisions when firms have information that investors do not have," Journal of Financial Economics, 187-221.

SCHOLES, M. S. (1972): "The Market for Securities: Substitution versus Price Pressure and the Effect of Information on Share Prices," Journal of Business, 45, 179-211.

SMITH, C.W. (1986): "Investment banking and the capital acquisition process," Journal of Financial Economics, 15, 3 - 29. 
Table 1. Descriptive statistics of the complete sample

\begin{tabular}{l|c|ccccc}
\hline Parameter & Units & Mean & Median & StdDev & Minimum & Maximum \\
\hline AMTISSD & USD, Mio. & 463.6 & 250.0 & 700.4 & 32.9 & $4{ }^{\prime} 693.2$ \\
MVISSUER & USD, Mio. & $18{ }^{\prime} 844$ & $5{ }^{\prime} 643$ & $25{ }^{\prime} 027$ & 133 & $899^{\prime} 860$ \\
PERCISSUER & $\%$ & $9.1 \%$ & $6.8 \%$ & $11.0 \%$ & $0.2 \%$ & $66.1 \%$ \\
COUPON & $\%$ & $1.8 \%$ & $1.5 \%$ & $1.4 \%$ & $0.0 \%$ & $6.5 \%$ \\
ANNTOISS & Days & 7.1 & 1.0 & 13.3 & 0.0 & 88.0 \\
MATURITY & Years & 6.8 & 5.1 & 3.5 & 3.0 & 20.1 \\
PREMIUM & $\%$ & $23.1 \%$ & $22.5 \%$ & $6.6 \%$ & $9.5 \%$ & $46.0 \%$ \\
DIVYIELD & $\%$ & $1.8 \%$ & $1.5 \%$ & $1.4 \%$ & $0.0 \%$ & $6.5 \%$ \\
VOLATILITY & $\%$ & $29.0 \%$ & $26.0 \%$ & $13.9 \%$ & $10.8 \%$ & $72.9 \%$ \\
DELTA & $\%$ & $58.5 \%$ & $56.7 \%$ & $11.5 \%$ & $36.1 \%$ & $99.3 \%$ \\
\hline
\end{tabular}

The complete sample consist of 55 convertibles and 28 exchangeables for the Swiss and German market. AMTISSD is the issuing amount. MVISSUER is the market value of the issuer 5 days before the announcement. PERCISSUER is the issuing amount per market value of issuer. ANNTOISS is the time between announcement an issue. PREMIUM is the conversion premium published by the issuer at announcement. DIVYIELD is the dividend yield 5 days before announcement. VOLATILITY is the volatility in the period [-220,-21]. DELTA is the sensitivity of the bond with respect to the underlying (Black-Scholes for European Call Options with Dividends). 
Table 2. Descriptive statistics and characteristics of the sub-samples Germany and Switzerland

\begin{tabular}{|c|c|c|c|c|c|c|c|c|c|}
\hline Country & AMTISSD & MVISSUER & PERCISSUER & COUPON & MATURITY & PREM IUM & DIVYIELD & VOLATILITY & DELTA \\
\hline Units & USD, Mio. & USD, Mio. & $\%$ & $\%$ & Years & $\%$ & $\%$ & $\%$ & $\%$ \\
\hline \multicolumn{10}{|l|}{ Germany (N=34) } \\
\hline Total & $20 \prime 608$ & & & & & & & & \\
\hline Mean & 604 & $19 ' 944$ & $8.4 \%$ & $2.3 \%$ & 6.41 & $25.4 \%$ & $1.3 \%$ & $32.8 \%$ & $64.4 \%$ \\
\hline Std. Dev. & 737 & $21^{\prime} 865$ & $11.5 \%$ & $1.5 \%$ & 3.59 & $8.0 \%$ & $1.1 \%$ & $14.1 \%$ & $11.0 \%$ \\
\hline \multicolumn{10}{|l|}{ Switzerland ( $N=49)$} \\
\hline Total & $17 ' 870$ & & & & & & & & \\
\hline Mean & 365 & $13^{\prime} 683$ & $9.5 \%$ & $1.5 \%$ & 7.03 & $21.5 \%$ & $1.1 \%$ & $26.7 \%$ & $58.4 \%$ \\
\hline Std. Dev. & 672 & 20017 & $10.6 \%$ & $1.2 \%$ & 3.55 & $5.0 \%$ & $0.7 \%$ & $13.4 \%$ & $11.8 \%$ \\
\hline Difference of means & 239 & 6'261 & $-1.1 \%$ & $0.8 \%$ & -0.62 & $3.9 \%$ & $0.3 \%$ & $6.1 \%$ & $6.0 \%$ \\
\hline t-value & $(1.52)$ & $(1.26)$ & $(0.42)$ & (2.6) & $(0.77)$ & (2.73) & $(1.27)$ & $(1.97)$ & (2.31) \\
\hline Significance & & & & $\star \star$ & & $\star * *$ & & * & ** \\
\hline
\end{tabular}

The securities of the complete sample are divided into the sub-sample Germany (34 securities) and Switzerland (49 securities) due to the domicile of the issuer for convertibles and due to the domicile of the underlying firm for exchangeables. t-values are calculated for a two side t-test with the null hypothesis of identical means. * denotes significant at the $10 \%$-level, ** denotes significant at the 5\%-level and *** denotes significant at the $1 \%$-level. AMTISSD is the issuing amount. MVISSUER is the market value of the issuer 5 days before the announcement. PERCISSUER is the issuing amount per market value of issuer. PREMIUM is the conversion premium published by the issuer at announcement. DIVYIELD is the dividend yield 5 days before announcement. VOLATILITY is the volatility in the period [-220,-21]. DELTA is the sensitivity of the bond with respect to the underlying (Black-Scholes for European Call Options with Dividends). 
Table 3. Descriptive statistics and characteristics of the sub-samples Convertibles and Exchangeables

\begin{tabular}{|c|c|c|c|c|c|c|c|c|c|c|c|}
\hline Security Type & AM TISSD & M VISSUER & PERCISSUER & MVUNDRL & $\begin{array}{c}\text { PERC- } \\
\text { UNDERL }\end{array}$ & COUPON & MATURITY & PREM IUM & DIVYIELD & VOLATILITY & DELTA \\
\hline Unit & USD, Mio. & USD, Mio. & $\%$ & USD, Mio. & $\%$ & $\%$ & Jahre & $\%$ & & $\%$ & $\%$ \\
\hline \multicolumn{12}{|l|}{ Convertibles $(\mathrm{N}=55)$} \\
\hline Total & $17 ’ 979$ & & & & & & & & & & \\
\hline Mean & 373 & $12 ’ 089$ & $11.1 \%$ & $\mathrm{~N} / \mathrm{A}$ & $\mathrm{N} / \mathrm{A}$ & $1.9 \%$ & 6.98 & $22.3 \%$ & $1.1 \%$ & $30.8 \%$ & $62.2 \%$ \\
\hline Std. Dev. & 521 & $19 ' 184$ & $11.8 \%$ & $\mathrm{~N} / \mathrm{A}$ & $\mathrm{N} / \mathrm{A}$ & $1.5 \%$ & 3.63 & $7.2 \%$ & $1.0 \%$ & $16.2 \%$ & $12.2 \%$ \\
\hline \multicolumn{12}{|c|}{ Exchangables $(\mathrm{N}=28)$} \\
\hline Total & $20 ' 499$ & & & & & & & & & & \\
\hline Mean & 642 & $27 ’ 409$ & $3.0 \%$ & $37 ’ 942$ & $2.7 \%$ & $1.6 \%$ & 6.33 & $24.6 \%$ & $1.2 \%$ & $25.5 \%$ & $58.3 \%$ \\
\hline Std. Dev. & 947 & $21^{\prime} 012$ & $2.6 \%$ & $33 ’ 555$ & $2.9 \%$ & $1.0 \%$ & 3.39 & $4.9 \%$ & $0.7 \%$ & $6.5 \%$ & $10.7 \%$ \\
\hline Difference of means & -269 & $-15{ }^{\prime} 321$ & $8.1 \%$ & $\mathrm{~N} / \mathrm{A}$ & $N / A$ & $0.3 \%$ & 0.65 & $-2.3 \%$ & $-0.1 \%$ & $5.3 \%$ & $3.9 \%$ \\
\hline $\mathrm{t}$-value & $(1.68)$ & $(2.97)$ & (3.01) & $\mathrm{N} / \mathrm{A}$ & $\mathrm{N} / \mathrm{A}$ & $(0.88)$ & $(0.79)$ & $(1.53)$ & $(0.34)$ & $(1.66)$ & $(1.44)$ \\
\hline Significance & * & 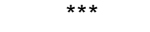 & 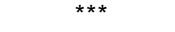 & & & & & & & & \\
\hline
\end{tabular}

The securities of the complete sample are divided into the sub-sample Convertibles (55 securities) and Exchangeables (28 securities). $\mathrm{t}$-values are calculated for a two side t-test with the null hypothesis of identical means. * denotes significant at the $10 \%$-level, ** denotes significant at the 5\%-level and *** denotes significant at the $1 \%$-level. AMTISSD is the issuing amount. MVISSUER is the market value of the issuer 5 days before the announcement. PERCISSUER is the issuing amount per market value of issuer. MVUNDERL is the market value of the underlying. PERCUNDERL is the issuing amount per market value of underlying company. PREMIUM is the conversion premium published by the issuer at announcement. DIVYIELD is the dividend yield 5 days before announcement. VOLATILITY is the volatility in the period [-220,-21]. DELTA is the sensitivity of the bond with respect to the underlying (Black-Scholes for European Call Options with Dividends). 
Table 4. Abnormal returns for the complete sample

\begin{tabular}{|c|c|c|c|c|c|c|c|c|c|c|c|c|}
\hline Days & & -5 & -4 & -3 & -2 & -1 & 0 & 1 & 2 & 3 & 4 & 5 \\
\hline AAR $\%$ & & 0.05 & 0.41 & 0.02 & 0.30 & 0.65 & -1.41 & -0.19 & 0.40 & 0.33 & -0.23 & 0.56 \\
\hline Stand. t-Test & Coeff. & $(-0.22)$ & (2.71) & $(0.53)$ & (3.06) & (2.94) & $(-5.96)$ & $(-0.50)$ & $(1.79)$ & $(1.43)$ & $(-1.31)$ & (2.14) \\
\hline & Sig. & & 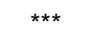 & & $\star \star \star *$ & $* * \star$ & $\star * *$ & & & & & $* *$ \\
\hline Rank Test & Coeff. & $(0.23)$ & $(-1.39)$ & $(0.08)$ & $(-2.37)$ & $(-2.38)$ & $(4.57)$ & $(0.91)$ & $(-1.59)$ & $(-1.32)$ & $(1.13)$ & $(-0.90)$ \\
\hline & Sig. & & & & $\star \star *$ & ** & $\star \star \star *$ & & & & & \\
\hline Period & & $-20,-2$ & $-5,-2$ & $-1,0$ & $-1,1$ & 0,1 & 2,5 & 2,20 & $-20,20$ & & & \\
\hline CAAR $\%$ & & 0.80 & 0.78 & -0.77 & -0.96 & -1.61 & 1.06 & 0.89 & 0.73 & & & \\
\hline Stand. t-Test & Coeff. & $(1.09)$ & (3.02) & $(-2.13)$ & $(-2.03)$ & $(-4.56)$ & (2.03) & $(0.48)$ & $(0.51)$ & & & \\
\hline & Sig. & & 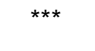 & $\star *$ & $* *$ & $* * *$ & $\star \star$ & & & & & \\
\hline Rank Test & Coeff. & $(-0.77)$ & $(-1.73)$ & $(1.55)$ & (1.79) & (3.88) & $(-1.34)$ & $(0.24)$ & $(-0.15)$ & & & \\
\hline & Sig. & & * & & * & $\star * \star$ & & & & & & \\
\hline
\end{tabular}

$*$ denotes significant at the $10 \%$-level, $* *$ denotes significant at the $5 \%$-level and $* * *$ denotes significant at the $1 \%$-level.

Table 5. Abnormal returns for the sub-samples Switzerland and Germany

\begin{tabular}{|c|c|c|c|c|c|c|c|c|c|c|c|c|}
\hline Days & & -5 & -4 & -3 & -2 & -1 & 0 & 1 & 2 & 3 & 4 & 5 \\
\hline Switzerland AAR \% & $\mathrm{N}=49$ & 0.10 & 0.27 & 0.04 & 0.34 & 0.65 & -0.84 & -0.19 & 0.33 & 0.39 & -0.14 & 0.12 \\
\hline Rank Test & $\begin{array}{l}\text { Coeff. } \\
\text { Sig. }\end{array}$ & $(-0.47)$ & $(-0.93)$ & $(0.07)$ & $(-1.97)$ & $\underset{\star(-2.29)}{\star \star}$ & $(1.87)$ & $(0.73)$ & $(-1.73)$ & $(-1.78)$ & $(1.18)$ & $(-0.68)$ \\
\hline $\begin{array}{l}\text { Germany AAR \% } \\
\text { Rank Test }\end{array}$ & $\begin{array}{l}\mathrm{N}=34 \\
\text { Coeff. } \\
\text { Sig. }\end{array}$ & $\begin{array}{l}-0.01 \\
(0.85)\end{array}$ & $\begin{array}{c}0.61 \\
(-1.08)\end{array}$ & $\begin{array}{l}-0.02 \\
(0.05)\end{array}$ & $\begin{array}{c}0.26 \\
(-1.41)\end{array}$ & $\begin{array}{c}0.64 \\
(-1.07)\end{array}$ & $\begin{array}{c}-2.24 \\
(4.85) \\
\star \star \star\end{array}$ & $\begin{array}{l}-0.19 \\
(0.57)\end{array}$ & $\begin{array}{c}0.50 \\
(-0.50)\end{array}$ & $\begin{array}{c}0.24 \\
(-0.04)\end{array}$ & $\begin{array}{l}-0.36 \\
(0.40)\end{array}$ & $\begin{array}{c}1.19 \\
(-0.62)\end{array}$ \\
\hline$t$-Test of means & $\begin{array}{l}\text { Coeff } \\
\text { Sig. }\end{array}$ & $(0.30)$ & $(0.93)$ & $(0.18)$ & $(0.16)$ & $(0.02)$ & $\begin{array}{c}(2.30) \\
\star \star\end{array}$ & $(0.00)$ & $(0.32)$ & $(0.39)$ & $(0.55)$ & $(1.27)$ \\
\hline Period & & $-20,-2$ & $-5,-2$ & $-1,0$ & $-1,1$ & 0,1 & 2,5 & 2,20 & $-20,20$ & & & \\
\hline $\begin{array}{l}\text { Switzerland CAAR \% } \\
\text { Rank Test }\end{array}$ & $\begin{array}{l}\mathrm{N}=49 \\
\text { Coeff. } \\
\text { Sig. }\end{array}$ & $\begin{array}{c}0.47 \\
(-0.95)\end{array}$ & $\begin{array}{c}0.74 \\
(-1.65)\end{array}$ & $\begin{array}{l}-0.19 \\
(-0.30)\end{array}$ & $\begin{array}{l}-0.38 \\
(0.18)\end{array}$ & $\begin{array}{c}-1.03 \\
(1.84) \\
*\end{array}$ & $\begin{array}{c}0.71 \\
(-1.50)\end{array}$ & $\begin{array}{c}0.42 \\
(0.08)\end{array}$ & $\begin{array}{c}0.51 \\
(-0.91)\end{array}$ & & & \\
\hline $\begin{array}{l}\text { Germany CAAR \% } \\
\text { Rank Test }\end{array}$ & $\begin{array}{l}\mathrm{N}=34 \\
\text { Coeff. } \\
\text { Sig. }\end{array}$ & $\begin{array}{c}1.26 \\
(-0.11)\end{array}$ & $\begin{array}{c}0.83 \\
(-0.79)\end{array}$ & $\begin{array}{c}-1.60 \\
(2.67) \\
\star \star \star \star\end{array}$ & $\begin{array}{c}-1.79 \\
(2.51) \\
\star \star\end{array}$ & $\begin{array}{c}-2.43 \\
(3.83) \\
\star \star \star\end{array}$ & $\begin{array}{c}1.57 \\
(-0.38)\end{array}$ & $\begin{array}{c}1.57 \\
(0.28)\end{array}$ & $\begin{array}{c}1.04 \\
(0.77)\end{array}$ & & & \\
\hline$t$-Test of means & $\begin{array}{l}\text { Coeff. } \\
\text { Sig. }\end{array}$ & $(0.10)$ & $(0.26)$ & $\begin{array}{c}(1.98) \\
*\end{array}$ & $\begin{array}{c}(1.95) \\
*\end{array}$ & $\underset{* \star}{(2.26)}$ & $(0.53)$ & $(0.29)$ & $(0.39)$ & & & \\
\hline
\end{tabular}


Table 6. Abnormal returns for the sub-samples Convertibles and Exchangeables

\begin{tabular}{|c|c|c|c|c|c|c|c|c|c|c|c|c|}
\hline Days & & -5 & -4 & -3 & -2 & -1 & 0 & 1 & 2 & 3 & 4 & 5 \\
\hline Convertible AAR \% & $\mathrm{N}=55$ & 0.00 & 0.42 & -0.08 & 0.34 & 0.94 & -1.12 & -0.24 & 0.51 & 0.52 & -0.12 & 0.67 \\
\hline \multirow[t]{2}{*}{ Rank Test } & Coeff. & $(-0.24)$ & $(-1.31)$ & $(-0.17)$ & $(-2.04)$ & $(-2.73)$ & $(2.54)$ & $(0.65)$ & $(-1.37)$ & $(-1.73)$ & $(0.48)$ & $(-0.23)$ \\
\hline & Sig. & & & & ** & $\star * \star$ & $\star *$ & & & & & \\
\hline Exchangeable AAR \% & $\mathrm{N}=28$ & 0.15 & 0.38 & 0.20 & 0.23 & 0.08 & -1.99 & -0.10 & 0.18 & -0.04 & -0.44 & 0.35 \\
\hline \multirow[t]{2}{*}{ Rank Test } & Coeff. & $(0.70)$ & $(-0.58)$ & $(0.37)$ & $(-1.24)$ & $(-0.32)$ & $(4.26)$ & $(0.66)$ & $(-0.84)$ & $(0.10)$ & $(1.25)$ & $(-1.21)$ \\
\hline & Sig. & & & & & & $\star * *$ & & & & & \\
\hline \multirow[t]{2}{*}{ t-Test of means } & Coeff & $(0.38)$ & $(0.08)$ & $(0.68)$ & $(0.37)$ & $(1.87)$ & $(1.62)$ & $(0.40)$ & $(0.66)$ & $(1.32)$ & $(0.86)$ & $(0.53)$ \\
\hline & Sig. & & & & & * & & & & & & \\
\hline Period & & $-20,-2$ & $-5,-2$ & $-1,0$ & $-1,1$ & 0,1 & 2,5 & 2,20 & $-20,20$ & & & \\
\hline Convertible CAAR $\%$ & $\mathrm{~N}=55$ & 0.98 & 0.69 & -0.18 & -0.43 & -1.36 & 1.58 & 1.86 & 2.42 & & & \\
\hline \multirow[t]{2}{*}{ Rank Test } & Coeff. & $(-1.29)$ & $(-1.88)$ & $(-0.13)$ & $(0.27)$ & $(2.26)$ & $(-1.42)$ & $(0.00)$ & $(-1.21)$ & & & \\
\hline & Sig. & & * & & & ** & & & & & & \\
\hline Exchangeable CAAR \% & $\mathrm{N}=28$ & 0.43 & 0.97 & -1.91 & -2.01 & -2.09 & 0.05 & -1.02 & -2.59 & & & \\
\hline \multirow[t]{2}{*}{ Rank Test } & Coeff. & $(0.44)$ & $(-0.37)$ & $(2.78)$ & $(2.65)$ & $(3.48)$ & $(-0.34)$ & $(0.40)$ & $(1.37)$ & & & \\
\hline & Sig. & & & $* * *$ & $* * *$ & $\star * *$ & & & & & & \\
\hline \multirow[t]{2}{*}{ t-Test of means } & Coeff. & $(1.17)$ & $(0.72)$ & $(2.80)$ & $(2.70)$ & $(2.23)$ & $(1.01)$ & $(1.19)$ & $(2.25)$ & & & \\
\hline & Sig. & & & $\star * *$ & $* * *$ & ** & & & ** & & & \\
\hline
\end{tabular}

$*$ denotes significant at the $10 \%$-level, $* *$ denotes significant at the $5 \%$-level and $* * *$ denotes significant at the $1 \%$-level.

Table 7. Abnormal returns at the issuance and announcement for the sub-sample issue

\begin{tabular}{|c|c|c|c|c|c|c|c|c|c|c|c|c|}
\hline Days & & -5 & -4 & -3 & -2 & -1 & 0 & 1 & 2 & 3 & 4 & 5 \\
\hline Issue AAR \% & $\mathrm{N}=36$ & 0.18 & 0.31 & 0.24 & -0.29 & 0.31 & 0.12 & 0.23 & 0.46 & 0.88 & -0.16 & -0.34 \\
\hline Rank Test & $\begin{array}{l}\text { Coeff. } \\
\text { Sig. }\end{array}$ & $(-0.72)$ & $(-0.70)$ & $(-1.06)$ & $(0.77)$ & $(-1.31)$ & $(-0.58)$ & $(-0.78)$ & $(-0.84)$ & $(-0.85)$ & $(1.21)$ & $(1.50)$ \\
\hline Announcement AAR \% & $\mathrm{N}=36$ & -0.04 & 0.78 & 0.34 & 0.44 & 0.58 & -1.12 & -0.09 & 0.58 & 0.26 & 0.01 & 1.67 \\
\hline \multirow[t]{2}{*}{ Rank Test } & Coeff. & $(0.41)$ & $(-1.87)$ & $(-1.06)$ & $(-1.51)$ & $(-0.90)$ & $(2.63)$ & $(0.39)$ & $(-0.18)$ & $(-0.60)$ & $(0.15)$ & $(-2.26)$ \\
\hline & Sig. & & & & & & $* * *$ & & & & & ** \\
\hline Period & & $-20,-2$ & $-5,-2$ & $-1,0$ & $-1,1$ & 0,1 & 2,5 & 2,20 & $-20,20$ & & & \\
\hline Issue CAAR \% & $\mathrm{N}=36$ & 2.95 & 0.44 & 0.44 & 0.67 & 0.35 & 0.82 & -0.38 & 3.23 & & & \\
\hline Rank Test & $\begin{array}{l}\text { Coeff. } \\
\text { Sig. }\end{array}$ & $(-0.85)$ & $(-0.85)$ & $(-1.33)$ & $(-1.54)$ & $(-0.96)$ & $(0.50)$ & $(1.30)$ & $(-0.19)$ & & & \\
\hline Announcement CAAR \% & $\mathrm{N}=36$ & 1.78 & 1.52 & -0.54 & -0.63 & -1.21 & 2.52 & 3.96 & 5.10 & & & \\
\hline \multirow[t]{2}{*}{ Rank Test } & Coeff. & $(-1.36)$ & $(-2.02)$ & $(1.22)$ & $(1.22)$ & (2.13) & $(-1.45)$ & $(-0.71)$ & $(-1.18)$ & & & \\
\hline & Sig. & & ** & & & ** & & & & & & \\
\hline
\end{tabular}

The sub-sample issue is defined for securities of the complete sample where the period between the announcement and the issue is at least two days. $*$ denotes significant at the $10 \%$-level, $* *$ denotes significant at the $5 \%$-level and *** denotes significant at the $1 \%$-level. 
Table 8. Cross-sectional analysis

\begin{tabular}{|c|c|c|c|c|c|c|c|c|c|}
\hline Reg \# & CONSTANT & DELTA & MARKETRETURN & DCOUNTRY & DTYPE & LNAMTISSD & LNMVUNDERL & PERCUNDER & Adj. $R^{2}$ \\
\hline (1) & $\begin{array}{c}\mathbf{0 . 0 3 4} \\
(1.83)\end{array}$ & $\begin{array}{l}-0.086 \\
(-2.74)\end{array}$ & & & & & & & 0.074 \\
\hline (2) & 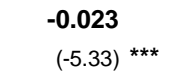 & & $\begin{array}{l}0.056 \\
(2.87)^{\star \star \star \star}\end{array}$ & & & & & & 0.081 \\
\hline (3) & $\begin{array}{l}\mathbf{0 . 0 3 0} \\
(1.71)^{*}\end{array}$ & 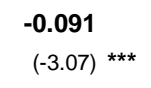 & $\begin{array}{l}0.059 \\
(3.18)^{\star * *}\end{array}$ & & & & & & 0.168 \\
\hline (4) & $\begin{array}{r}\mathbf{0 . 0 2 2} \\
(1.12)\end{array}$ & $\begin{array}{l}-0.083 \\
(-2.74)^{* * *}\end{array}$ & $\begin{array}{l}0.056 \\
(3.03)^{* * *}\end{array}$ & $\begin{array}{r}\mathbf{0 . 0 0 7} \\
(1.01)\end{array}$ & & & & & 0.168 \\
\hline (5) & $\begin{array}{r}\mathbf{0 . 0 2 7} \\
(1.54)\end{array}$ & $\begin{array}{l}-0.097 \\
(-3.28)\end{array}$ & $\begin{array}{l}0.058 \\
(3.17)^{* * *}\end{array}$ & & $\begin{array}{r}\mathbf{0 . 0 1 0} \\
(1.43)\end{array}$ & & & & 0.178 \\
\hline (6) & $\begin{array}{r}\mathbf{0 . 0 3 8} \\
(1.49)\end{array}$ & $\begin{array}{l}-0.090 \\
(-2.98)\end{array}$ & $\begin{array}{l}0.056 \\
(2.88)^{* \star \star}\end{array}$ & & & $\begin{array}{r}-0.002 \\
(-0.44)\end{array}$ & & & 0.159 \\
\hline (7) & $\begin{array}{r}\mathbf{0 . 0 2 0} \\
(0.77)\end{array}$ & $\begin{array}{l}-0.090 \\
(-2.99)\end{array}$ & $\begin{array}{l}\mathbf{0 . 0 6 0} \\
(3.20) \text { ***}\end{array}$ & & & & $\begin{array}{r}\mathbf{0 . 0 0 1} \\
(0.51)\end{array}$ & & 0.160 \\
\hline (8) & $\begin{array}{l}\mathbf{0 . 0 3 0} \\
(1.67)^{*}\end{array}$ & $\begin{array}{l}-0.089 \\
(-2.91)\end{array}$ & $\begin{array}{l}0.059 \\
(3.17)^{* \star *}\end{array}$ & & & & & $\begin{array}{r}-0.010 \\
(-0.30)\end{array}$ & 0.158 \\
\hline (9) & $\begin{array}{r}\mathbf{0 . 0 2 3} \\
(0.81)\end{array}$ & $\begin{array}{l}-0.092 \\
(-2.90)\end{array}$ & $\begin{array}{l}0.056 \\
(2.88) * * *\end{array}$ & $\begin{array}{r}0.005 \\
(0.69)\end{array}$ & $\begin{array}{r}\mathbf{0 . 0 0 9} \\
(1.18)\end{array}$ & $\begin{array}{l}0.000 \\
(-0.06)\end{array}$ & & & 0.162 \\
\hline (10) & $\begin{array}{r}-0.018 \\
(-0.57)\end{array}$ & $\begin{array}{l}-0.088 \\
(-2.85) \text { *** }\end{array}$ & $\begin{array}{l}0.059 \\
(3.20) * * *\end{array}$ & $\begin{array}{r}\mathbf{0 . 0 0 7} \\
(0.96)\end{array}$ & $\begin{array}{l}\mathbf{0 . 0 1 5} \\
(1.84)^{*}\end{array}$ & & $\begin{array}{r}\mathbf{0 . 0 0 3} \\
(1.59)\end{array}$ & & 0.189 \\
\hline (11) & $\begin{array}{r}\mathbf{0 . 0 1 9} \\
(0.98)\end{array}$ & $\begin{array}{l}-0.086 \\
(-2.70)\end{array}$ & $\begin{array}{l}0.057 \\
(3.04)^{* \star \star}\end{array}$ & $\begin{array}{r}\mathbf{0 . 0 0 6} \\
(0.76)\end{array}$ & $\begin{array}{c}\mathbf{0 . 0 1 2} \\
(1.46)\end{array}$ & & & $\begin{array}{r}-0.033 \\
(-0.91)\end{array}$ & 0.171 \\
\hline
\end{tabular}

OLS regression results (in regression (6) to (11) we omit two of the three parameters LNAMTISSD, LNMVUNDERL and PERCUNDERL respectively due to correlation between these three parameters) with the cumulative abnormal return for the period [0,1] for the convertibles and exchangeables as the dependent variable. $*$ denotes significant at the $10 \%$-level, $* *$ denotes significant at the $5 \%$-level and $* * *$ denotes significant at the $1 \%$-level. 
Table 9. Cross-sectional analysis for the sub-samples convertibles and exchangeables

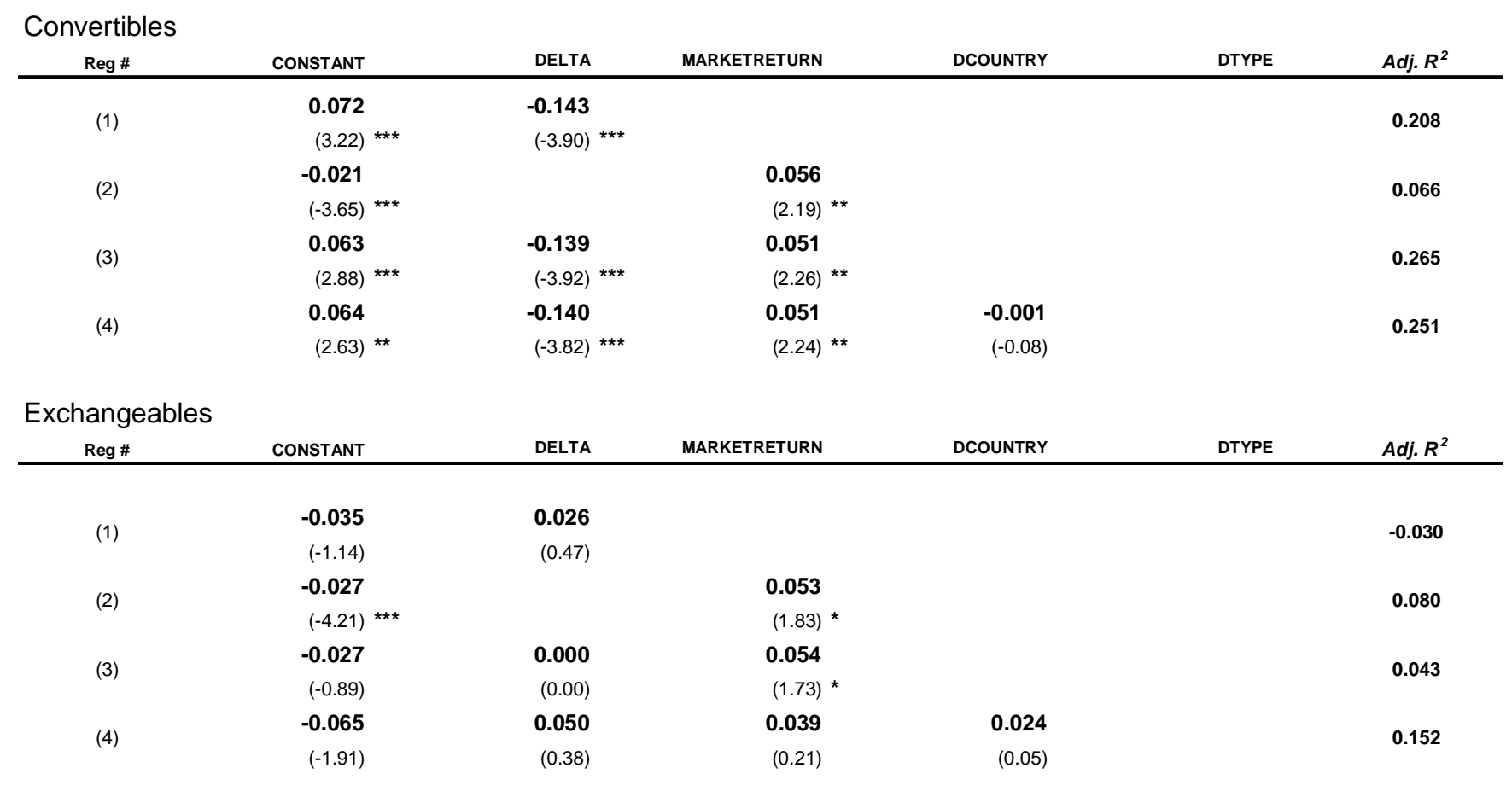

Regression results with the cumulative abnormal return for the period [0,1] for the convertibles and exchangeables as the dependent variable $*$ denotes significant at the $10 \%$-level, $* *$ denotes significant at the 5\%-level and $* * *$ denotes significant at the $1 \%$-level. 